\title{
Crop Establishment Methods and Zinc Fertilization Affects Nutrients Content and Their Uptake of Direct-Seeded Rice
}

\author{
Sushil Kumar* and S.K. Verma \\ Department of Agronomy, Institute of Agricultural Sciences, Banaras Hindu University, \\ Varanasi- 221 005, India \\ *Corresponding author
}

\section{A B S T R A C T}

\section{Keywords}

Crop establishment methods, Directseeded rice,

Nutrient content, Nutrient uptake, Zinc fertilization

Article Info

Accepted: 07 November 2018 Available Online: 10 December 2018
An experiment consisting of three crop establishment methods in the main plots and five zinc fertilization in the sub-plots was undertaken in a split-plot design with three replications at Varanasi during Kharif season of 2016-17 and 2017-18. Data on N, P, K and $\mathrm{Zn}$ content (grain and straw) and their uptake were recorded. Crop establishment methods significantly influenced $\mathrm{Zn}$ content, and $\mathrm{N}, \mathrm{P}, \mathrm{K}$ and $\mathrm{Zn}$ uptake whereas $\mathrm{Zn}$ fertilization influenced significantly $\mathrm{N}, \mathrm{P}, \mathrm{K}$ and $\mathrm{Zn}$ content and their uptake. Results revealed that among crop establishment methods, conventional till-wet direct seeded rice estimated higher N, P, K and Zn content and their uptake. In the case of $\mathrm{Zn}$ fertilization, 6 $\mathrm{kg} \mathrm{Zn} \mathrm{ha-1} \mathrm{(basal} \mathrm{application)} \mathrm{was} \mathrm{proved} \mathrm{superior} \mathrm{over} \mathrm{rest} \mathrm{of} \mathrm{the} \mathrm{treatments} \mathrm{for} \mathrm{N}$, $\mathrm{P}$ and $\mathrm{K}$ content and their uptake. However, with respect to $\mathrm{Zn}$ content and its uptake, $6 \mathrm{~kg} \mathrm{Zn}$ $\mathrm{ha}^{-1}$ (foliar application) was adjudged better as compared to other treatments. Based on the results, it is said in the conclusion that conventional till-wet direct seeded rice and $6 \mathrm{~kg} \mathrm{Zn}$ $\mathrm{ha}^{-1}$ (basal application) was found better for $\mathrm{N}, \mathrm{P}$ and $\mathrm{K}$ content and their uptake.

\section{Introduction}

Rice (Oryza sativa L.) is a staple food for about $60 \%$ of the world population and plays a prominent role in the economic and social stability of the world. Across the world, it is cultivated in 161.30 million hectare (mha) area with total production and productivity of 486.30 million tonnes (mt) and $4510 \mathrm{~kg} \mathrm{ha}^{-1}$, respectively. Among rice-growing countries, India is the second largest producer of rice after China (USDA, 2017). In India, rice is grown on about 43.38 mha area having production of $104.32 \mathrm{mt}$ with productivity
$2404 \mathrm{~kg} \mathrm{ha}^{-1}$. Among the state, Uttar Pradesh is the second largest rice growing state after West Bengal having 5.85 mha area with production and productivity of $12.50 \mathrm{mt}$ and $2132 \mathrm{~kg} \mathrm{ha}^{-1}$, respectively (Directorate of Economics and Statistics, 2017). Rice cultivation is in crisis across the globe due to shrinking area, fluctuating annual production, stagnating yield and exacerbating inputs (seed, fertilizers and labour) price. Hence, the cost of cultivation of paddy is alarmingly increasing. Furthermore, labour and water scarcity is making the rice cultivation an uphill task. Therefore, it is the need of the hour to devise 
alternate ways to cultivate rice with less water and inputs.

Direct-seeded rice (DSR) is the technology in which lees water, labour and energy are required and hence it can be a potential alternative to conventional puddled transplanted rice (PTR) (Kumar and Ladha, 2011). The sowing of rice in DSR is done under puddled and non-puddled conditions (Joshi et al., 2013) so that the crop is not subjected to transplanting stress (Singh et al., 2008). DSR has several advantages including early maturity of crop and it also produces almost at par yield with the transplanted crop (Awan et al., 2006). As per the need of the hour, DSR is being practiced with various modifications of tillage/land preparation and crop establishment (CE) to suit site-specific requirements but has not yet gained popularity, even though many research studies suggest its benefits over TPR. Tillage practices (TPs) such as zero-tillage (ZT) and un-puddled sowing have been shown to be beneficial in terms of improving soil health, water use, crop productivity and farmers' income (Singh et al., 2009). Globally, among micronutrients, zinc ( $\mathrm{Zn})$ deficiency is one of the important abiotic factors limiting rice productivity in addition to being a major nutritional disorder affecting human health (Alloway, 2009). The problem of low availability of $\mathrm{Zn}$ in soils dominated by rice production is well known throughout the world, but it is more severe in India, Pakistan, China, Australia, Turkey and USA (Singh and Shivay, 2015). Fertilization of rice crop with $\mathrm{Zn}$ has a positive impact on rice yield (Shivay et al., 2015) and also improves Zn content in rice grain which helps in alleviating $\mathrm{Zn}$ deficiency, which rank fifth among the most important health risk factor in developing countries and eleventh globally (Palmgren et al., 2008). Thus, keeping the above points in mind, the present study was conducted to evaluate the effect of crop establishment methods and $\mathrm{Zn}$ fertilization on nutrients content and their uptake by the DSR.

\section{Materials and Methods}

Field experiment involving three crop establishment methods viz., conventional tilldirect seeded rice (CT-DSR), conventional till-wet direct seeded rice (CT-WDSR) and zero till-direct seeded rice (ZT-DSR) as main plot treatments and five zinc fertilization viz., Control (no $\mathrm{Zn}$ application), $3 \mathrm{~kg} \mathrm{Zn} \mathrm{ha}{ }^{-1}$ (basal application), $3 \mathrm{~kg} \mathrm{Zn} \mathrm{ha} \mathrm{(foliar}$ application), $6 \mathrm{~kg} \mathrm{Zn} \mathrm{ha-1} \mathrm{(basal} \mathrm{application)}$ and $6 \mathrm{~kg} \mathrm{Zn} \mathrm{ha}^{-1}$ (foliar application) as subplot treatments in a split-plot design with three replications at Agricultural Research Farm, Institute of Agricultural Sciences, Banaras Hindu University, Varanasi, situated at $25^{\circ} 15 ' 26.9^{\prime \prime} \quad \mathrm{N}$ Latitude, $82^{0} 59^{\prime} 17.1^{\prime \prime} \quad \mathrm{E}$ longitude and at an altitude of 74.4 meters above the mean sea level during Kharif season of 2016-17 and 2017-18. The site of the experiment was homogeneously fertile with uniform textural make-up and had slightly slopy topography. The soil of the experimental field was sandy clay loam in texture with moderate fertility had low organic carbon $(0.46 \%)$ and available nitrogen $\left(204 \mathrm{~kg} \mathrm{ha}^{-1}\right)$, and medium available phosphorus $\left(22 \mathrm{~kg} \mathrm{ha}^{-1}\right)$ and potassium $\left(222 \mathrm{~kg} \mathrm{ha}^{-1}\right)$ but was found deficient in $\mathrm{Zn}(0.53 \mathrm{ppm})$. In addition to the above, soil also indicated slightly alkaline behaviour with $\mathrm{pH}$ 7.5. The experimental site received 1094.8 and $641.4 \mathrm{~mm}$ total rainfall in 2016-17 and 2017-18, respectively with the highest amount of rainfall in the month of July during both the years of cropping period. The maximum and minimum temperature was ranged between $29.2-37.1^{\circ} \mathrm{C}$ and $15.3-26.9^{\circ} \mathrm{C}$ in $2016-17$ and $30.1-37.6^{\circ} \mathrm{C}$ and $16.8-27.8^{\circ} \mathrm{C}$ in 2017-18, respectively. The experimental field was prepared as per treatments specification and sowing of the crop using seed rate@30 kg ha ${ }^{-1}$ was done with the help of zero till seed drill and drum seeder at the 
row-to-row spacing of $20 \mathrm{~cm}$ on June 30 and 24 in 2016-17 and 2017-18, respectively. Rice variety (HUR-105) known for its promising performance under irrigated conditions of Varanasi region of the Eastern Uttar Pradesh was used as test crop for the investigation. A uniform dose of $120 \mathrm{~kg} \mathrm{~N}, 60 \mathrm{~kg} \mathrm{P}_{2} \mathrm{O}_{5}$ and 60 $\mathrm{kg} \mathrm{K}_{2} \mathrm{O} \mathrm{ha}^{-1}$ was applied in all the treatments through urea $(46 \% \mathrm{~N})$, DAP $\left(46 \% \mathrm{P}_{2} \mathrm{O}_{5}\right)$ and muriate of potash $\left(60 \% \mathrm{~K}_{2} \mathrm{O}\right)$, respectively. Half of the total $\mathrm{N}$ and full dose of $\mathrm{P}$ and $\mathrm{K}$ were applied as the basal application just before sowing. However, remaining half dose of $\mathrm{N}$ in the form of urea was top dressed in two equal splits at active tillering and panicle initiation stages, respectively during both the years. Zinc sulphate fertilizer was applied as per treatments specification as basal and two equal foliar splits $(0.25$ and $0.5 \% \mathrm{Zn}$ solution) at 15 and 30 DAS. The source of $\mathrm{Zn}$ fertilizer was $\mathrm{ZnSO}_{4} \cdot \mathrm{H}_{2} \mathrm{O}$ with $33 \% \mathrm{Zn}$ content. For weed management, two herbicides (pendimethalin@1 kg a.i. ha ${ }^{-1}$ at 2 DAS and bispyribac-Na@25 g a.i. ha ${ }^{-1}$ at 20 DAS) was sprayed using knapsack sprayer with the flat fan nozzle. The need-based irrigations were also given to fulfil the water requirement of crop and to keep the crop in vigorous condition during both the years of investigation. At maturity, the crop was harvested manually with the help of sickle on November, 15 and 9 in 2016-17 and 2017-18, respectively. The representative plant samples (grain and straw) from harvested produced were collected and analyzed for $\mathrm{N}, \mathrm{P}, \mathrm{K}$ and $\mathrm{Zn}$ contents. Similarly, N was estimated by using modified Kjeldahal method as described by (Jackson, 1973), P by Vanadomolybdate phosphoric yellow colour method as described by (Jackson, 1973), K by Flame photometer as described by (Jackson, 1973) and Zn by Atomic Absorption Spectrophotometer (AAS) as per (Lindsay and Norvell, 1978) and subsequently their uptake by grain, straw and total uptake (grain + straw) was worked out as per following equations:
Nutrient uptake by grain $\left(\mathrm{kg} \mathrm{ha}^{-1}\right)=$ Nutrient content $(\%)^{X}$ grain yield $\left(\mathrm{kg} \mathrm{ha}^{-1}\right)$

Nutrient uptake by straw $\left(\mathrm{kg} \mathrm{ha}^{-1}\right)=$ Nutrient content $(\%)^{X}$ straw yield $\left(\mathrm{kg} \mathrm{ha}^{-1}\right)$

Total nutrient uptake $\left(\mathrm{kg} \mathrm{ha}^{-1}\right)=$ Nutrient uptake (Grain) + Nutrient uptake (straw)

The statistical analysis of data was done using analysis of variance as described by (Gomez and Gomez, 1984) and the comparisons were made at 5 per cent level of significance.

\section{Results and Discussion}

\section{Nutrient content}

Data pertaining to the grain and straw $\mathrm{N}, \mathrm{P}, \mathrm{K}$ and $\mathrm{Zn}$ content are presented in Table 1 . It is seen from the table that the crop establishment methods significantly influenced $\mathrm{Zn}$ content but not $\mathrm{N}, \mathrm{P}$ and $\mathrm{K}$ content in grain and straw. However, $\mathrm{Zn}$ fertilization significantly $(\mathrm{P}=0.05)$ influenced the $\mathrm{N}, \mathrm{P}, \mathrm{K}$ and $\mathrm{Zn}$ content in grain and straw of DSR. Among crop establishment methods, conventional tillwet direct seeded rice estimated higher $\mathrm{N}, \mathrm{P}$, $\mathrm{K}$ and $\mathrm{Zn}$ content whereas, lower $\mathrm{N}, \mathrm{P}, \mathrm{K}$ and $\mathrm{Zn}$ content was recorded with zero till-direct seeded rice. The higher and lower $\mathrm{N}, \mathrm{P}, \mathrm{K}$ and $\mathrm{Zn}$ content estimated with conventional tillwet direct seeded rice and zero till-direct seeded rice, respectively might be due to higher and lower dry matter accumulation. In case of $\mathrm{Zn}$ fertilization treatments, $6 \mathrm{~kg} \mathrm{Zn} \mathrm{ha}{ }^{-}$ ${ }^{1}$ (basal application) followed by $6 \mathrm{~kg} \mathrm{Zn} \mathrm{ha}{ }^{-1}$ (foliar application), $3 \mathrm{~kg} \mathrm{Zn} \mathrm{ha-1} \mathrm{(basal}$ application), $3 \mathrm{~kg} \mathrm{Zn} \mathrm{ha}{ }^{-1}$ (foliar application) and control treatments, respectively estimated higher $\mathrm{N}, \mathrm{P}$ and $\mathrm{K}$ content in both (grain and straw). However, with respect to $\mathrm{Zn}$ content, 6 $\mathrm{kg} \mathrm{Zn} \mathrm{ha}{ }^{-1}$ (foliar application) was found superior over rest of the treatments. The higher $\mathrm{N}, \mathrm{P}$ and $\mathrm{K}$ content estimated with $6 \mathrm{~kg}$ $\mathrm{Zn} \mathrm{ha}{ }^{-1}$ (basal application) might be due to higher dry matter accumulation. However, higher $\mathrm{Zn}$ content observed with the foliar 
application was probably due to more retention of $\mathrm{Zn}$ in the plant system. Our results confirm the research findings of Kumar et al., (2016); Ghoneim (2016); Kumar et al., (2017) and Farooq et al., (2018).

\section{Nutrient uptake}

Crop establishment methods and $\mathrm{Zn}$ fertilization significantly $(\mathrm{P}=0.05)$ influenced the N, P, K and Zn uptake by grain, straw and total of DSR (Table 2). Among crop establishment methods, conventional till-wet direct seeded rice and zero till-direct seeded rice recorded higher and lower uptake of $\mathrm{N}$ by grain, straw and both. This might be due to higher and lower dry matter accumulation recorded with conventional till-wet direct seeded rice and zero till-direct seeded rice, respectively. These results are in line with the research findings of Yadav et al., (2014) and Meena et al., (2016). With respect to $\mathrm{Zn}$ fertilization treatments, $6 \mathrm{~kg} \mathrm{Zn} \mathrm{ha}^{-1}$ (basal application) followed by $6 \mathrm{~kg} \mathrm{Zn} \mathrm{ha}^{-1}$ (foliar application) observed higher $\mathrm{N}$ uptake by grain, straw and both of DSR might be due to higher dry matter accumulation. Our results are in conformity with the research finding of Kumar et al., (2016).

With respect to $\mathrm{P}$ uptake conventional till-wet direct seeded rice and zero till-direct seeded rice recorded higher and lower uptake by grain, straw and both might be due to higher and lower dry matter accumulation observed with conventional till-wet direct seeded and zero till-direct seeded rice, respectively. Results are in congruence with the research findings of Yadav et al., (2014) and Meena et al., (2016). Among $\mathrm{Zn}$ fertilization treatments, $6 \mathrm{~kg} \mathrm{Zn} \mathrm{ha}^{-1}$ (basal application) was proved superior and recorded higher $\mathrm{P}$ uptake by grain, straw and both might be due to higher dry matter accumulation. However, the lower P uptake was recorded with control treatment. Our results are in agreement with the research finding of Kumar et al., (2016).

Table.1 Effect of crop establishment methods and Zn fertilization on N, P, K and Zn content of direct-seeded rice (mean data of two years)

\begin{tabular}{|c|c|c|c|c|c|c|c|c|}
\hline \multirow[b]{2}{*}{ Treatments } & \multicolumn{2}{|c|}{$\mathbf{N}$ content $(\%)$} & \multicolumn{2}{|c|}{ P content $(\%)$} & \multicolumn{2}{|c|}{ K content $(\%)$} & \multicolumn{2}{|c|}{ Zn content ( $\left.\mathrm{mg} \mathrm{kg}^{-1}\right)$} \\
\hline & Grain & Straw & Grain & Straw & Grain & Straw & Grain & Straw \\
\hline \multicolumn{9}{|l|}{ Crop establishment methods } \\
\hline Conventional till-direct seeded rice & 1.15 & 0.53 & 0.235 & 0.123 & 0.316 & 1.58 & 27.96 & 49.83 \\
\hline $\begin{array}{l}\text { Conventional till-wet direct seeded } \\
\text { rice }\end{array}$ & 1.16 & 0.55 & 0.242 & 0.128 & 0.322 & 1.61 & 29.47 & 51.39 \\
\hline Zero till-direct seeded rice & 1.13 & 0.51 & 0.233 & 0.119 & 0.311 & 1.56 & 26.41 & 45.83 \\
\hline $\operatorname{SEm} \pm$ & 0.02 & 0.01 & 0.005 & 0.003 & 0.006 & 0.02 & 0.48 & 0.76 \\
\hline $\mathrm{CD}(\mathrm{P}=0.05)$ & NS & NS & NS & NS & NS & NS & 1.90 & 3.00 \\
\hline \multicolumn{9}{|l|}{ Zn fertilization } \\
\hline Control (no Zn) & 1.08 & 0.48 & 0.214 & 0.100 & 0.298 & 1.49 & 20.32 & 40.88 \\
\hline $3 \mathrm{~kg} \mathrm{Zn} \mathrm{ha}^{-1}$ (basal application) & 1.16 & 0.53 & 0.229 & 0.128 & 0.312 & 1.61 & 27.18 & 47.02 \\
\hline $3 \mathrm{~kg} \mathrm{Zn} \mathrm{ha}^{-1}$ (foliar application) & 1.12 & 0.51 & 0.226 & 0.113 & 0.312 & 1.54 & 30.58 & 51.98 \\
\hline $6 \mathrm{~kg} \mathrm{Zn} \mathrm{ha}^{-1}$ (basal application) & 1.19 & 0.58 & 0.261 & 0.143 & 0.332 & 1.66 & 30.01 & 50.95 \\
\hline $6 \mathrm{~kg} \mathrm{Zn} \mathrm{ha}^{-1}$ (foliar application) & 1.16 & 0.55 & 0.253 & 0.131 & 0.327 & 1.62 & 31.63 & 54.25 \\
\hline SEm \pm & 0.01 & 0.01 & 0.010 & 0.003 & 0.006 & 0.01 & 0.50 & 0.42 \\
\hline $\mathrm{CD}(\mathrm{P}=0.05)$ & 0.02 & 0.02 & 0.028 & 0.009 & 0.017 & 0.03 & 1.47 & 1.23 \\
\hline
\end{tabular}


Table.2 Effect of crop establishment methods and Zn fertilization on $\mathrm{N}$ and $\mathrm{P}$ uptake of directseeded rice (mean data of two years)

\begin{tabular}{|c|c|c|c|c|c|c|}
\hline \multirow[t]{2}{*}{ Treatments } & \multicolumn{3}{|c|}{$\begin{array}{l}\text { N uptake } \\
\left(\mathrm{kg} \mathrm{ha}^{-1}\right)\end{array}$} & \multicolumn{3}{|c|}{$\begin{array}{l}\text { P uptake } \\
\left(\mathrm{kg} \mathrm{ha}^{-1}\right)\end{array}$} \\
\hline & Grain & Straw & Total & Grain & Straw & Total \\
\hline \multicolumn{7}{|l|}{ Crop establishment methods } \\
\hline Conventional till-direct seeded rice & 43.56 & 29.90 & 73.46 & 8.95 & 7.01 & 15.96 \\
\hline Conventional till-wet direct seeded rice & 46.24 & 32.55 & 78.79 & 9.69 & 7.57 & 17.25 \\
\hline Zero till-direct seeded rice & 40.83 & 28.00 & 68.82 & 8.43 & 6.49 & 14.93 \\
\hline $\mathrm{SEm} \pm$ & 0.97 & 0.80 & 1.75 & 0.24 & 0.20 & 0.40 \\
\hline $\mathrm{CD}(\mathrm{P}=\mathbf{0 . 0 5})$ & 3.80 & 3.15 & 6.89 & 0.94 & 0.79 & 1.59 \\
\hline \multicolumn{7}{|l|}{ Zn fertilization } \\
\hline Control (no Zn) & 37.43 & 25.52 & 62.95 & 7.38 & 5.35 & 12.73 \\
\hline $3 \mathrm{~kg} \mathrm{Zn} \mathrm{ha}^{-1}$ (basal application) & 44.11 & 30.22 & 74.33 & 8.70 & 7.25 & 15.95 \\
\hline $3 \mathrm{~kg} \mathrm{Zn} \mathrm{ha}{ }^{-1}$ (foliar application) & 41.22 & 28.36 & 69.58 & 8.32 & 6.31 & 14.63 \\
\hline $6 \mathrm{~kg} \mathrm{Zn} \mathrm{ha}^{-1}$ (basal application) & 49.15 & 34.55 & 83.70 & 10.76 & 8.59 & 19.35 \\
\hline $6 \mathrm{~kg} \mathrm{Zn} \mathrm{ha}^{-1}$ (foliar application) & 45.80 & 32.09 & 77.89 & 9.97 & 7.61 & 17.58 \\
\hline $\mathrm{SEm} \pm$ & 0.50 & 0.65 & 0.79 & 0.41 & 0.19 & 0.44 \\
\hline $\mathrm{CD}(\mathrm{P}=0.05)$ & 1.46 & 1.89 & 2.29 & 1.19 & 0.55 & 1.28 \\
\hline
\end{tabular}

Table.3 Effect of crop establishment methods and $\mathrm{Zn}$ fertilization on $\mathrm{K}$ and $\mathrm{Zn}$ uptake of directseeded rice (mean data of two years)

\begin{tabular}{|c|c|c|c|c|c|c|}
\hline \multirow[t]{2}{*}{ Treatments } & \multicolumn{3}{|c|}{$\begin{array}{l}\text { K uptake } \\
\left(\mathrm{kg} \mathrm{ha}^{-1}\right)\end{array}$} & \multicolumn{3}{|c|}{$\begin{array}{c}\text { Zn uptake } \\
\left(\mathrm{kg} \mathrm{ha}^{-1}\right)\end{array}$} \\
\hline & Grain & Straw & Total & Grain & Straw & Total \\
\hline \multicolumn{7}{|l|}{ Crop establishment methods } \\
\hline Conventional till-direct seeded rice & 11.99 & 89.82 & 101.81 & 0.107 & 0.284 & 0.391 \\
\hline Conventional till-wet direct seeded rice & 12.85 & 95.08 & 107.93 & 0.118 & 0.304 & 0.422 \\
\hline Zero till-direct seeded rice & 11.26 & 84.99 & 96.25 & 0.096 & 0.250 & 0.346 \\
\hline SEm \pm & 0.27 & 1.72 & 1.84 & 0.003 & 0.007 & 0.010 \\
\hline $\mathrm{CD}(\mathrm{P}=0.05)$ & 1.06 & 6.76 & 7.21 & 0.012 & 0.028 & 0.038 \\
\hline \multicolumn{7}{|l|}{ Zn fertilization } \\
\hline Control (no Zn) & 10.31 & 79.16 & 89.48 & 0.070 & 0.217 & 0.288 \\
\hline $3 \mathrm{~kg} \mathrm{Zn} \mathrm{ha}^{-1}$ (basal application) & 11.88 & 91.70 & 103.58 & 0.104 & 0.268 & 0.371 \\
\hline $3 \mathrm{~kg} \mathrm{Zn} \mathrm{ha}^{-1}$ (foliar application) & 11.45 & 85.33 & 96.77 & 0.113 & 0.289 & 0.402 \\
\hline $6 \mathrm{~kg} \mathrm{Zn} \mathrm{ha}^{-1}$ (basal application) & 13.68 & 99.53 & 113.21 & 0.124 & 0.306 & 0.430 \\
\hline $6 \mathrm{~kg} \mathrm{Zn} \mathrm{ha}^{-1}$ (foliar application) & 12.86 & 94.09 & 106.95 & 0.125 & 0.316 & 0.440 \\
\hline SEm \pm & 0.23 & 1.07 & 1.07 & 0.002 & 0.004 & 0.004 \\
\hline $\mathrm{CD}(\mathrm{P}=0.05)$ & 0.66 & 3.14 & 3.13 & 0.006 & 0.011 & 0.012 \\
\hline
\end{tabular}


In case of $\mathrm{K}$ uptake conventional till-wet direct seeded rice followed by conventional till-direct seeded rice and zero till-direct seeded rice, respectively were proved superior might be due to the difference in dry matter accumulation. These results support the research findings of Yadav et al., (2014) and Meena et al., (2016). Likewise, with respect to $\mathrm{Zn}$ fertilization treatments, $6 \mathrm{~kg} \mathrm{Zn} \mathrm{ha-1} \mathrm{(basal} \mathrm{application)}$ followed by $6 \mathrm{~kg} \mathrm{Zn} \mathrm{ha-1} \mathrm{(foliar} \mathrm{application)}$ recorded higher $\mathrm{K}$ uptake by grain, straw and both might be due to higher dry matter accumulation. However, the lower $\mathrm{K}$ uptake was recorded with control treatment. Our results are in analogues with the research finding of Kumar et al., (2016).

Among crop establishment methods, conventional till-wet direct seeded rice and zero till-direct seeded rice recorded higher and lower uptake of $\mathrm{Zn}$ by grain, straw and both. This was might be due to higher and lower dry matter accumulation recorded with conventional tillwet direct seeded and zero till-direct seeded rice, respectively. These results are in line with the research findings of Yadav et al., (2014) and Meena et al., (2016).

With respect to $\mathrm{Zn}$ uptake, $6 \mathrm{~kg} \mathrm{Zn} \mathrm{ha}^{-1}$ (foliar application) followed by $6 \mathrm{~kg} \mathrm{Zn} \mathrm{ha-1} \mathrm{(basal}$ application), $3 \mathrm{~kg} \mathrm{Zn} \mathrm{ha}{ }^{-1}$ (basal application), 3 $\mathrm{kg} \mathrm{Zn} \mathrm{ha}{ }^{-1}$ (foliar application) and control treatment, respectively were proved better. The higher uptake of Zn by different parts of DSR with foliar application of $6 \mathrm{~kg} \mathrm{Zn} \mathrm{ha}{ }^{-1}$ was recorded might be due to the higher yield, dry matter production and $\mathrm{Zn}$ content. These results are in congruence with the research findings of Kandali et al., (2015) and Kumar et al., (2017).

Based on the above results it is suggested that conventional till-wet direct seeded rice proved to be better for $\mathrm{N}, \mathrm{P}, \mathrm{K}$ and $\mathrm{Zn}$ content and their uptake. In case of $\mathrm{Zn}$ fertilization, basal application of $6 \mathrm{~kg} \mathrm{Zn} \mathrm{ha}{ }^{-1}$ found superior for $\mathrm{N}$, $\mathrm{P}$ and $\mathrm{K}$ content and their uptake. However, with respect to $\mathrm{Zn}$ content and its uptake foliar application of $6 \mathrm{~kg} \mathrm{Zn} \mathrm{ha}{ }^{-1}$ adjudged superior.

\section{References}

Alloway, B.J. 2009. Soils factors associated with zinc deficiency in crops and humans. Environment Geochemical and Health. 31, 537-548.

Awan, T.H., Ali, I., Manzoor, Z., Safdar, I., and Ashraf, M. 2006. Economic effect of different plant establishment techniques on rice production. Journal of Agricultural Research. 9, 580-588.

Directorate of Economics and Statistics. 2017. Ministry of Agriculture and Farmers Welfare, Government of India, Agricultural statistical data.

Farooq, M., Ullah, A., Rehman, A., Nawaz, A., Nadeem, A., Wakeel, A., Nadeem, F., and Siddique, K.H.M. 2018. Application of zinc improves the productivity and biofortification of fine grain aromatic rice grown in dry seeded and puddled transplanted production systems. Field Crops Research. DOI: 10.1016/j.fcr.2017.11.004.

Ghoneim, A.M. 2016. Effect of different methods of $\mathrm{Zn}$ application on rice growth, yield and nutrients dynamics in plant and soil. Journal of Agricultural and Ecology Research International. 6(2), 1-9.

Gomez, K.A., and Gomez, A.A. 1984. Statistical Procedures for Agricultural Research. 2 Edition. A Wiley Inter science Publication, New York, 657 p.

Jackson, M.L. 1973. Soil chemical analysis, Perntice Hall of India Pvt. Ltd., New Delhi, pp.183.

Joshi, E., Kumar, D., Lal, B., Nepalia, V., Gautam, P., and Vyas, A. K. 2013. Management of direct seeded rice for enhanced resource-use efficiency. Plant Knowledge Journal. 2(3), 119-134.

Kandali, G.S., Basumatary, A., Barua, N.G., Medhi, B.K., and Hazarika, S. 2015. Response of rice to zinc application in acidic soils of Assam. Annals of Plant and Soil Research. 17(1), 74-76.

Kumar, D., Uppal, R.S., Ram, H., and Dhaliwal, S.S. 2016. Effect of $\mathrm{N}, \mathrm{Zn}$ and $\mathrm{Fe}$ Application on N, P, K content and their 
total uptake in Parmal rice (Oryza sativa L.). Progressive Agriculture. 16(1), 7176.

Kumar, S., Dwivedi, A., Kumar, V., Ansari, M.Q., and Naresh, R.K. 2017. Effect of precision land levelling and Zinc bioavailability: Water use, productivity and input use efficiency in transition from flooded to aerobic rice (Oryza sativa). International Journal of Chemical Studies. 5(4), 110-118.

Kumar, V., and Ladha, J.K. 2011. Direct seeding of rice: recent developments and future research needs. Advances in Agronomy. 111, 297.

Lindsay, W.L., and Norvell, A. 1978. Development of DTPA soil test for zinc, iron, manganese and copper, Soil Science Society of America Journal. 42, 421-428.

Meena, H.N., Bohra, J.S., Jinger, D., and Rajpoot, S.K. 2016. Effect of tillage and crop establishment methods on productivity, profitability and quality of rice under rice-wheat cropping system. Annals of Agricultural Research New Series. 37 (4), 369-373.

Palmgren, M.G., Clemens, S., Williams, L.E., Kramer, U., Borg, S., Schjorring, J.K., and Sanders, D. 2008. Zn biofortification of cereals: problems and solutions. Trends in Plant Science. 13(9), 464-473.

Shivay, Y.S., Prasad, R., Singh, R.K., and Pal, M. 2015. Relative efficiency of zinccoated urea and soil and foliar application of zinc sulphate on yield, nitrogen, phosphorus, potassium, zinc and iron biofortification in grains and uptake by basmati rice (Oryza sativa L.). Journal of Agricultural Science. 7(2), 161-173.

Singh, A., and Shivay, Y.S. 2015. Zinc application and green manuring enhances growth and yield in basmati rice (Oryza sativa L.). Indian Journal of Plant Physiology. 20(3), 289-296.

Singh, U.P., Singh, Y., Kumar, V., and Ladha, J.K. 2009. Evaluation and promotion of resource conserving tillage and crop establishment technique in rice-wheat system of eastern India. (In): Ladha J.K., Singh Y., Erenstein, O., Hardy, B., (Eds.), Integrated crop and resource management in rice-wheat system of south Asia. International Rice Research Institute, Los Banos, Philippines. pp. 151-176.

Singh, Y., Singh, V.P., Chauhan, B., Orr, A., Mortimer, A.M., Johnson, D.E., and Hardy, B. 2008. Direct seeding of rice and weed management in the irrigated rice-wheat cropping system of the IndoGangetic Plains. Los Baños (Philippines): International Rice Research Institute, and Pantnagar (India): Directorate of Experiment Station, G.B. Pant University of Agriculture and Technology, pp. 272.

United States Department of Agriculture, World rice supply and utilization, 2017.

Yadav, S., Evangelista, G., Faronilo, J., Humphreys, E., Henry, A., and Fernandez, L. 2014. Establishment method effects on crop performance and water productivity of irrigated rice in the tropics. Field Crops Research. 166, 112127.

\section{How to cite this article:}

Sushil Kumar and Verma, S.K. 2018. Crop Establishment Methods and Zinc Fertilization Affects Nutrients Content and their Uptake of Direct-Seeded Rice. Int.J.Curr.Microbiol.App.Sci. 7(12): 655-661. doi: https://doi.org/10.20546/ijcmas.2018.712.081 